\title{
PERBANDINGAN PENILAIAN TINGKAT KESEHATAN BANK \\ DENGAN MENGGUNAKAN METODE RGEC PADA LIMA BANK YANG MASUK KATEGORI BUKU 4 DI INDONESIA PERIODE 2016
}

\section{THE COMPARASION OF BANK RATING USING RGEC METHOD TO THE FIVE TOP BANKS WHICH IS IN BOOK 4, 2016 IN INDONESIA}

\author{
Ika Wulandari \\ Prodi Akuntansi FE Universitas Mercubuana Yogyakarta \\ Email : ichawulan7@gmail.com
}

\begin{abstract}
Abstrak
Tingkat kesehatan bank yang baik dapat dipergunakan oleh masyarakat sebagai tolak ukur dari kinerja suatu bank. Penelitian ini bertujuan untuk mengetahui perbandingan penilaian tingkat kesehatan bank berdasarkan metode RGEC (Risk Profile, Good Corporate Governance, Earnings dan Capital) pada lima bank besar yang masuk dalam kategori BUKU 4 pada tahun 2016. Kelima bank tersebut yaitu Bank Mandiri, Bank BNI, Bank BRI, Bank BCA dan Bank CIMB Niaga. Komponen yang digunakan untuk melakukan penilaian meliputi rasio NPL, LDR, IRR, Good Corporate Governance yang diukur dengan penilaian self assessment, ROA, NIM dan rasio CAR. Berdasarkan hasil penelitian diperoleh hasil bahwa Bank BCA mempunyai penilaian kesehatan yang paling baik dengan bobot nilai 97,14 \%, Bank Mandiri dengan bobot nilai 91,43\%, Bank BRI dengan bobot nilai $88,5 \%$, Bank BNI dengan bobot nilai $88,57 \%$ dan Bank CIMB Niaga dengan bobot nilai $82,86 \%$. Dari hasil tersebut, keempat bank yang memiliki bobot nilai di atas $86 \%$ memperoleh predikat Sangat Sehat, sedangkan Bank CIMB Niaga memperoleh predikat Sehat.
\end{abstract}

Kata kunci : Tingkat Kesehatan Bank, Risk Profile, Good Corporate Governance, Earnings, Capital

\begin{abstract}
A good bank soundness can be used by the community as a benchmark of bank performance. This study aims to determine the comparasion of banks soundness rating based on RGEC method (Risk Profile, Good Corporate Governance, Earnings and Capital) to five top banks that are stated ini BUKU 4 2016. The five banks are Bank Mandiri, BNI, BRI, BCA and Bank CIMB Niaga. The components used for the assessment are NPL ratio, LDR, IRR, Good Corporate Governance as measured by self assessment, ROA, NIM and CAR ratio. The result of the research it is found that $B C A$ has the highest rating with 97,14\%, Bank Mandiri 91,43\%, Bank BRI 88,5\%, Bank BNI $88,5 \%$ and CIMB Niaga 82,86\%. According the result, the four banks tahat have value above $86 \%$ get the very healthy predicate while Bank CIMB Niaga get the healthy predicate.
\end{abstract}

Keyword : Health Level of Banks, Risk Profile, Good Corporat Governance, Earnings, Capital

\section{PENDAHULUAN}

Bank merupakan lembaga keuangan yang aktivitasnya meliputi pengumpulan dana, penyaluran dana dan memberikan layanan atau jasa perbankan lainnya. Bank juga merupakan lembaga kepercayaan masyarakat yang mempunyai kedudukan sebagai penunjang pembangunan. 
Dalam menjalankan kegiatannya bank merupakan industri yang mengandalkan kepercayaan sehingga harus selalu menjaga kesehatannya. Pemeliharaan kesehatan tersebut harus tercermin dari beberapa aspek yang digunakan sebagai standar atau tolak ukur untuk menilai kesehatan bank. Beberapa hal yang perlu diperhatikan menyangkut aspek permodalan, aktiva, manajemen, profit dan tingkat likuiditas yang memadahi. Dengan kata lain, tingkat kesehatan bank juga erat kaitannya dengan pemenuhan peraturan perbankan atau kepatuhan terhadap otoritas pengawas bank.

Kesehatan bank merupakan hal yang penting bagi semua pihak, baik bagi pemilik bank, manajemen bank, masyarakat, maupun otoritas pengawas bank. Hal ini digunakan sebagai sarana untuk mengevaluasi kinerja bank sesuai dengan prinsip kehati-hatian dan kepatuhan terhadap ketentuan yang berlaku. Hasil penilaian kesehatan bank oleh pemilik dan manajemen bank dapat digunakan sebagai sarana untuk menantukan strategi dan perencanaan di masa yang akan datang, sedangakan bagi nasabah atau masyarakat dapat digunakan sebagai sarana monitor to monitor mengingat bahwa nasabah sudah mempercayakan dananya untuk dikelola pihak bank. Bagi investor hal tersebut dapat digunakan untuk mendapatkan informasi yang cukup mengenai kinerja pihak manajemen bank, seperti kemampuan untuk memperoleh laba atau keuntungan, sehingga dapat digunakan sebagai bahan pertimbangan untuk melakukan investasi.

Metode penilaian kesehatan bank mengalami beberapa kali perubahan, sebelum diperkenalkan metode RGEC dan CAMELS, terlebih dahulu Bank Indonesia memperkenalkan metode CAMEL. CAMEL (Capital, Asset, Management, Earnings, Liquidity) pertama kali diperkenalkan di Indonesia sejak dikeluarkannya Paket Februari 1991 mengenai sifat-sifat kehati-hatian bank. Paket tersebut dikeluarkan sebagai dampak kebijakan Paket Kebijakan 27 Oktober 1988 (Pakto 1988). CAMEL berkembang di Indonesia menjadi CAMELS (Capital, Asset quality, Management, Earnings, Liquidity, dan Sensitivity to Market Risk) sesuai dengan Pearturan Bank Indonesia Nomor : 6/10/PBI/2004. Kriteria sensitivity to market risk merupakan aspek tambahan dari metode penilaian kesehatan bank yang sebelumnya, yaitu CAMEL.

Pada tahun 2011 sesuai dengan Peraturan Bank Indonesia Nomor 13/PBI/2011 tentang penilaian kesehatan bank, metode yang digunakan berubah menjadi metode Risk Based Bank Rating atau RBBR. Aspek yang dinilai pada metode tersebut adalah aspek Risk Profile, Good Corporate Governance, Earnings dan Capital (RGEC). Dalam peraturan terebut semua bank umum diwajibkan untuk melakukan penilaian tingkat kesehatan sendiri (self assessment) dengan menggunakan pendekatan risiko. Untuk perhitungan penilaian kesehatan bank berpedoman pada Surat Edaran Bank Indonesia (SEBI) No 13/24/DPNP. Perkembangan metode penilaian kesehatan bank yang bersifat dinamis ini diharapkan mampu mencerminkan kondisi bank yang sebenarnya pada saat ini maupun di masa yang akan datang.

Penelitian ini dilakukan pada lima bank yang masuk dalam kategori BUKU (Bank Umum Kelompok Usaha) empat (4) dilihat dari sisi modal inti yang dimiliki. Sesuai dengan POJK No. 6 /POJK.03/2016 berdasarkan modal inti bank, bank dikelompokkan menjadi empat kelompok usaha yang meliputi ;

a. BUKU 1 yaitu bank dengan modal inti kurang dari Rp.1 triliun

b. BUKU 2 yaitu bank dengan modal inti Rp.1 triliun sampai dengan kurang dari Rp.5 triliun

c. BUKU 3 yaitu bank dengan modal inti Rp.5 Triliun sampai dengan kurang dari Rp.30 triliun

d. BUKU 4 yaitu bank dengan modal inti diatas Rp.30 triliun

Modal inti adalah modal yang terdiri dari modal disetor ditambah dengan cadangan yang dibentuk dari laba setelah pajak. Menurut PBI No 15/12/PBI/2013, modal inti 
terdiri dari modal inti utama dan modal inti tambahan, dimana modal inti utama terdiri dari modal disetor dan cadangan tambahan modal.

Adapun bank yang masuk pada kategori BUKU 4 pada tahun 2016 adalah :

Tabel 1. Bank yang Masuk Kategori BUKU 4 per 31 Desember 2016

\begin{tabular}{clc}
\hline \multirow{2}{*}{ No } & \multicolumn{1}{|}{ Nama Bank } & $\begin{array}{c}\text { Modal Inti per 31 Desember 2016 } \\
(\mathbf{R p})\end{array}$ \\
\hline 1 & Bank Rakyat Indonesia (BRI) & 136,786 triliun \\
2 & Bank Negara Indonesia (BNI) & 79,645 triliun \\
3 & Bank Mandiri & 130,356 triliun \\
4 & Bank Central Asia (BCA) & 105,542 triliun \\
5 & Bank CIMB Niaga & 32,046 triliun \\
\hline
\end{tabular}

Sumber : Laporan Keuangan Tahunan 2016 masing-masing bank

Dari kelima bank tersebut terdapat tiga bank milik pemerintah yang masuk dalam kategori BUKU 4 yaitu Bank Rakyat Indonesia, Bank Negara Indonesia, Bank Mandiri dan dua bank milik swasta yaitu Bank Central Asia (BCA) dan Bank CIMB Niaga.

\section{TUJUAN PENELITIAN}

Berdasarkan perumusan di atas, tujuan dari penelitian ini adalah untuk ; (1) Mengetahui tingkat kesehatan pada bank yang masuk kategori BUKU 4 dengan menggunakan metode RGEC untuk periode tahun 2016 (2) Membandingkan tingkat kesehatan bank pada bank yang masuk kategori BUKU 4 dengan menggunakan metode RGEC untuk periode tahun 2016.

\section{TINJAUAN PUSTAKA}

Bank

Menurut UU No. 10 tahun 1998 Bank adalah badan usaha yang menghimpun dana dari masyarakat dalam bentuk simpanan dan menyalurkan kepada masyarakat dalam kredit dan atau bentuk-bentuk lainnya dalam rangka meningkatkan taraf hidup rakyat banyak. Bank dikenal sebagai lembaga keuangan yang kegiatannya utamanya menghimpun dana, menyalurkan dana dan sebagai perantara jasa lalu lintas pembayaran.

\section{Tingkat Kesehatan Bank}

Tingkat kesehatan bank merupakan kemampuan suatu bank untuk melakukan kegiatan operasional perbankan secara normal dan mampu memenuhi semua kewajibannya dengan baik dengan cara yang sesuai dengan peraturan perbankan yang berlaku (Triandaru dan Budisantoso, 2006: 51). Teori regulasi digunakan sebagai landasan dalam penelitian ini dikarenakan hal ini berkaitan dengan regulasi yang dilakukan dan dikeluarkan oleh otoritas pengawas bank.

Sedangkan berdasarkan PBI No. 13/1/PBI/2011 tingkat kesehatan bank didefinisikan sebagai hasil penilaian kualitatif atas berbagai aspek yang berpengaruh terhadap kondisi atau kinerja suatu bank melalui penilaian kuantitatif dan kualitatif terhadap faktor-faktor profil risiko, Good Corporate Governance, rentabilitas dan permodalan.

\section{Metode RGEC}

Metode RGEC didasarkan pada Peraturan Bank Indonesia Nomor 13/1/PBI/2011 tanggal 5 Januari 2011 yang mulai berlaku sejak tanggal 1 Januari 2012. Adapun 
cakupan penilaian meliputi aspek Profil risiko (risk profile), Good Corporate Governance $(G C G)$, rentabilitas (earnings), dan permodalan (capital).

\section{Risk Profile (Profil Risiko)}

Menurut Peraturan Bank Indonesia No. 13/ 1/ PBI/ 2011 profil risiko merupakan penilaian terhadap risiko inheren dan kualitas penerapan manajemen risiko dalam operasional bank yang dilakukan terhadap delapan risiko yaitu risiko kredit, risiko pasar, risiko likuiditas, risiko operasional, risiko hukum, risiko stratejik, risiko kepatuhan dan risiko reputasi.

Penelitian ini mengukur faktor Risk Profile dengan menggunakan tiga indikator. Pertama untuk mengukur faktor risiko kredit dengan menggunakan rumus Non Performing Loan (NPL), kedua risiko likuiditas dengan menggunakan rumus Loan to Deposit Ratio (LDR), dan ketiga risiko pasar dengan menggunakan rumus Interest Rate Risk (IRR). Pengukuran hanya dilakukan terhadap tiga risiko, karena hanya dari ketiga risiko tersebut dapat diperoleh data kuantitatif yang tidak dapat diperoleh dari faktor risiko operasional, risiko hukum, risiko stratejik, risiko kepatuhan dan risiko reputasi.

a. Risiko Kredit

Untuk mengukur risiko kredit dilakukan dengan menggunakan rasio Non Performing Loan (NPL).

Rasio NPL merupakan perbandingan kredit bermasalah di bank dengan jumlah kredit yang disalurkan. Kredit bermasalah adalah kredit yang masuk dalam kategori kolektibilitas kurang lancar, diragukan dan macet sehingga rasio NPL yang digunakan adalah NPL Gross. Rasio ini mengindikasikan semakin tinggi rasio NPL menunjukkan semakin buruk kualitas kreditnya

$$
N P L=\frac{\text { Kredit bermasalah }}{\text { Total Kredit }} \times 100 \%
$$

Tabel 2. Matriks Kriteria Penetapan Peringkat Komposit untuk NPL

\begin{tabular}{cll}
\hline PK & Rasio NPL & Keterangan \\
\hline $\mathbf{1}$ & NPL $\leq 2 \%$ & Sangat baik \\
$\mathbf{2}$ & $2 \%<\mathrm{NPL}<5 \%$ & Baik \\
$\mathbf{3}$ & $5 \% \leq \mathrm{NPL} \leq 8 \%$ & Cukup baik \\
$\mathbf{4}$ & $8 \% \leq \mathrm{NPL} \leq 12 \%$ & Kurang baik \\
$\mathbf{5}$ & $\mathrm{NPL} \geq 12 \%$ & Tidak Baik \\
\hline
\end{tabular}

Sumber : Kodifikasi Bank Indonesia, 2012

b. Risiko Likuiditas

Risiko Likuiditas diukur dengan menggunakan rasio Loan to Deposit Ratio (LDR). LDR adalah rasio antara besarnya seluruh volume kredit yang disalurkan oleh bank dan jumlah penerimaan dana dari berbagai sumber. Kredit yang diberikan tidak termasuk kredit kepada bank lain. Dana Pihak Ketiga (DPK) merupakan dana yang berasal dari nasabah yang meliputi simpanan dalam bentuk giro, tabungan dan deposito. Semakin kecil rasio ini menunjukkan semakin kecil dana dari pihak ketiga yang digunakan untuk penempatan kredit.

$$
L D R=\frac{\text { Total Kredit }}{\text { Dana Pihak Ketiga }} \times 100 \%
$$


Tabel 3. Matriks Kriteria Penetapan Peringkat Komposit untuk LDR

\begin{tabular}{ccl}
\hline PK & \multicolumn{1}{c}{ Rasio LDR } & Keterangan \\
\hline 1 & $50 \%<$ LDR $\leq 75 \%$ & Sangat baik \\
2 & $75 \%<$ LDR $<85 \%$ & Baik \\
3 & $85 \%<$ LDR $\leq 100 \%$ & Cukup baik \\
4 & $100 \%<$ LDR $\leq 110 \%$ & Kurang baik \\
$\mathbf{5}$ & LDR $>110 \%$ & Tidak Baik \\
\hline
\end{tabular}

c. Risiko Pasar

Sumber : Kodifikasi Bank Indonesia, 2012

Risiko Pasar diukur dengan menggunakan Interest Rate Risk Ratio (Rasio IRR). Rasio ini menunjukkan perbandingan tingkat spread yang terjadi antara pendapatan bunga dan beban bunga. Semakin kecil rasio ini, maka risiko pasar yang terjadi semakin besar. Rasio IRR dapat diukur dengan menggunakan rumus sebagai berikut :

$$
I R R=\frac{\text { Pendapatan bunga }}{\text { Beban Bunga }} \times 100 \%
$$

Tabel 4. Matriks Kriteria Penetapan Peringkat Komposit untuk IRR

\begin{tabular}{cll}
\hline PK & Rasio IRR & Keterangan \\
\hline 1 & IRR $>45 \%$ & Sangat baik \\
2 & $41 \% \leq \mathrm{IRR} \leq 45 \%$ & Baik \\
3 & $36 \% \leq \mathrm{IRR} \leq 40 \%$ & Cukup baik \\
4 & $31 \% \leq \mathrm{IRR} \leq 35 \%$ & Kurang baik \\
5 & IRR $\leq 30 \%$ & Tidak Baik \\
\hline
\end{tabular}

Sumber : SE Bank Indonesia tahun 2011

\section{Good Corporate Governance (GCG)}

Good Corporate Governance dianalisis berdasarkan pada Peraturan Bank Indonesia No.13/1/PBI/2011 dengan mencari laporan tahunan yang dipublikasikan dan menetapkan penilaian yang dilakukan oleh bank berdasarkan sistem self assessment. GCG dinilai berdasarkan tiga aspek utama yang meliputi Governance Structure, Governance Process dan Governance Outcomes.

Governance Structure meliputi pelaksanaan tugas dan tanggungjawab Komisaris dan Direksi serta kelengkapan dan pelaksanaan tugas komite. Governance Process meliputi penerapan fungsi kepatuhan bank, penanganan benturan kepentingan, penerapan fungsi audit intern dan ekstern, penerapan manajemen risiko dan sistem rencana strategis bank. Governance Outcomes meliputi transparansi kondisi keuangan dan non keuangan, pelaporan internal dan laporan pelaksanaan GCG. 


\section{Earnings (Rentabilitas)}

Faktor rentabilitas dinilai dengan menggunakan dua rasio yaitu Return on Asset (ROA) dan rasio Net Interest Margin (NIM). Rasio idi digunakan untuk mengukur kemampuan manajemen dalam menghasilkan laba atau keuntungan.

a. Return on Asset (ROA)

ROA mengindikasikan kemampun perusahaan untuk menghasilkan keuntungan dari aset yang dimilikinya. Semakin tinggi rasio ini mengindikasikan semakin baik kinerja dari bank tersebut.

$$
R O A=\frac{\text { Laba sebelum pajak }}{\text { Rata }- \text { rata aset }} \times 100 \%
$$

Tabel 5. Matriks Kriteria Penetapan Peringkat Komposit untuk ROA

\begin{tabular}{cll}
\hline PK & Rasio ROA & Keterangan \\
\hline 1 & ROA $>1,5 \%$ & Sangat baik \\
2 & $1,25 \%<$ ROA $\leq 1,5 \%$ & Baik \\
3 & $0,5 \%<$ ROA $\leq 1,25 \%$ & Cukup baik \\
4 & $0 \%<$ ROA $\leq 0,5 \%$ & Kurang baik \\
5 & ROA $<0 \%$ & Tidak Baik \\
\hline \multicolumn{2}{l}{ Sumber : Kodifikasi Bank Indonesia, 2012 }
\end{tabular}

b. Net Interest Margin (NIM)

NIM mengindikasikan kemampuan bank dalam menghasilkan pendapatan bunga bersih dengan penempatan aktiva produktif. Aktiva produktif merupakan jenis aktiva yang mampu menghasilkan pendapatan bagi pihak bank. Semakin besar rasio ini mengindikasikan semakin baik kinerja bank dalam menghasilkan pendapatan bunga.

$$
N I M=\frac{\text { Pendapatan bunga bersih }}{\text { Rata }- \text { rata aktiva produktif }} \times 100 \%
$$

Tabel 6. Matriks Kriteria Penetapan Peringkat Komposit untuk NIM

\begin{tabular}{cll}
\hline PK & Rasio NIM & Keterangan \\
\hline 1 & NIM $>3 \%$ & Sangat baik \\
2 & $2 \%<$ NIM $\leq 3 \%$ & Baik \\
3 & $1,5 \%<$ NIM $\leq 2 \%$ & Cukup baik \\
4 & $1 \%<$ NIM $\leq 1,5 \%$ & Kurang baik \\
5 & NIM $\leq 1 \%$ & Tidak Baik \\
\hline \multicolumn{2}{c}{ Sumber : Kodifikasi Bank Indonesia, 2012 }
\end{tabular}

\section{Capital (Permodalan)}

Riyadi (2006:171) mengatakan bahwa setiap bank yang beroperasi di Indonesia diwajibkan untuk memelihara Kewajiban Penyediaan Modal Minimum (KPMM) atau Capital Adequacy Ratio (CAR). Tinggi rendahnya CAR suatu bank dipengaruhi oleh dua faktor utama yaitu besarnya modal yang dimiliki bank dan jumlah Aktiva Tertimbang Menurut Risiko (ATMR) bank tersebut. Semakin tinggi rasio CAR mengindikasikan semakin sehat permodalan bank tersebut.

$$
C A R=\frac{\text { Modal Bank }}{A T M R} \times 100 \%
$$


Tabel 7. Matriks Kriteria Penetapan Peringkat Komposit untuk CAR

\begin{tabular}{lll}
\hline PK & Rasio CAR & Keterangan \\
\hline 1 & CAR $\geq 12 \%$ & Sangat baik \\
2 & $9 \% \leq \mathrm{CAR}<12 \%$ & Baik \\
3 & $8 \% \leq \mathrm{CAR}<9 \%$ & Cukup baik \\
4 & $6 \%<\mathrm{CAR}<8 \%$ & Kurang baik \\
5 & CAR $\leq 6 \%$ & Tidak Baik \\
\hline \multicolumn{2}{l}{ Sumber : Kodifikasi Bank Indonesia, 2012 }
\end{tabular}

\section{Menentukan Bobot Nilai atau Peringkat Komposit Tingkat Kesehatan Bank}

Langkah terakhir dari penilaian tingkat kesehatan bank adalah menghitung bobot yang diperoleh dari keseluruhan peringkat komposit (PK) masing-masing komponen penilaian.
a. PK $1=$ untuk setiap checklist dikalikan dengan 5
b. PK $2=$ untuk setiap checklist dikalikan dengan 4
c. PK $3=$ untuk setiap checklist dikalikan dengan 3
d. PK $4=$ untuk setiap checklist dikalikan dengan 2
e. PK 5 = untuk setiap checklist dikalikan dengan 1

Tabel 8. Peringkat Kesehatan Bank dengan Pendekatan RGEC atau RBBR (Risk Based Bank Ranking)

\begin{tabular}{cll}
\hline PK & Bobot (\%) & Keterangan \\
\hline 1 & $86-100$ & Sangat Sehat \\
2 & $71-85$ & Sehat \\
3 & $61-70$ & Cukup Sehat \\
4 & $41-60$ & Kurang Sehat \\
5 & $<40$ & Tidak Sehat
\end{tabular}

Sumber : Analisis Laporan Keuangan : Penilaian Kesehatan Bank (Ngadirin Setiawan, 2012)

\section{METODE}

Dalam penelitian ini jenis penelitian yang digunakan adalah penelitian deskriptif dengan pendekatan kuantitatif yaitu dengan cara menganalisis laporan keuangan dan ditabulasikan sesuai dengan kategori perusahaan tersebut. Penelitian deskriptif merupakan penelitian yang dimaksudkan untuk menyelidiki keadaan, kondisi atau hal lain yang sudah disebutkan yang hasilnya dipaparkan dalam bentuk laporan penelitian.

Penelitian ini dilakukan pada lima bank besar yang masuk dalam kategori BUKU 4 dengan modal inti di atas Rp 30 triliun. Kelima bank yang diteliti adalah Bank Mandiri,Bank Negara Indonesia (BNI), Bank Rakyat Indonesia (BRI), Bank Mandiri, Bank Central Asia (BCA) dan Bank CIMB Niaga dengan periode penelitian tahun 2016.

Teknik pengumpulan data menggunakan metode dokumentasi dengan cara mengumpulkan data sekunder yang diambil dari Laporan Keuangan tahunan masingmasing bank. Analisis data dilakukan dengan menggunakan rasio keuangan. Rasio keuangan yang digunakan tergantung dari aspek yang diteliti. Analisis data dilakukan dengan cara menganalisis Risk profil dengan menggunakan rasio NPL dan LDR, menganalisis Good corporate governance dengan penilaian secara self assessment masing-masing bank, menganalisis Earnings dengan menggunakan Rasio ROA dan NIM, menganalisis Capital dengan menggunakan rasio CAR. Langkah terakhir adalah 
melakukan penghitungan bobot nilai untuk tingkat kesehatan bank dan membandingkan hasil penilaian tingkat kesehatan berdasarkan bobot nilai antar bank yang diteliti

\section{HASIL DAN PEMBAHASAN}

Berdasarkan analisis data yang dilakukan dengan menggunakan data yang diperoleh dari Laporan Keuangan masing-masing bank, diperoleh data sebagai berikut :

1. Analisis Risk Profile

a. Risiko Kredit

Dengan menggunakan rasio Non Performing Loan (NPL) diperoleh hasil pada tahun 2016 sebagai berikut :

Tabel 9. Ringkasan Penilaian NPL pada tahun 2016

\begin{tabular}{cccccc}
\hline Ket & Mandiri & BNI & BRI & BCA & $\begin{array}{c}\text { CIMB } \\
\text { Niaga }\end{array}$ \\
\hline $\begin{array}{c}\text { NPL (\%) } \\
\text { Komposit }\end{array}$ & 3,96 & 3 & 2,03 & 1,31 & 3,9 \\
Predikat & Baik & 2 & 2 & 1 & 2 \\
Baik & Baik & $\begin{array}{c}\text { Sangat } \\
\text { baik }\end{array}$ & \begin{tabular}{c} 
Baik \\
\hline
\end{tabular} \\
\hline
\end{tabular}

$\overline{\text { Sumber : Laporan keuangan tahunan bank yang diteliti tahun } 2016}$
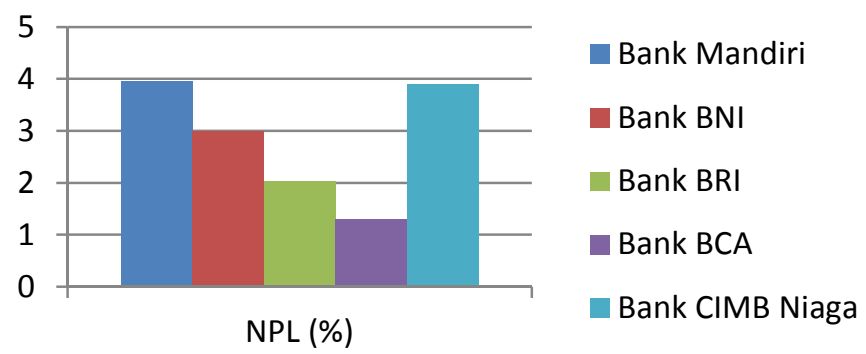

Grafik 1. Perbandingan NPL pada bank yang diteliti tahun 2016

Hasil penilaian NPL gross menunjukkan bahwa Bank BCA mempunyai rasio yang paling baik dibandingkan dengan bank lain yang diteliti, dengan rasio NPL yang paling rendah 1,31\% sehingga mendapatkan Peringkat Komposit 1 dengan predikat sangat baik. Hal ini dikarenakan rasio NPL Bank BCA tidak melebihi $2 \%$. Sedangkan untuk keempat bank lain yang diteliti mendapatkan Peringkat Komposit 2 dengan predikat baik untuk NPL, karena rasio NPL berkisar lebih dari $2 \%$ dan kurang dari $5 \%$. Secara berturutturut bank berikutnya yang mempunyai rasio NPL yang baik setelah Bank BCA adalah Bank BRI dengan rasio NPL 2,03\%, Bank BNI dengan rasio NPL $3 \%$, Bank CIMB Niaga dengan rasio NPL 3,9 \% dan yang terakhir Bank Mandiri dengan rasio NPL 3,96 $\%$.

b. Risiko Likuiditas

Berikut ini hasil dari penilaian risiko likuiditas dengan menggunakan rasio Loan to Deposit Ratio (LDR). Hasil penilaian risiko likuiditas dengan menggunakan rasio LDR menunjukkan bahwa Bank BCA memperoleh peringkat komposit yang paling baik jika dibandingkan dengan bank lain yang diteliti yaitu komposit 2 dengan rasio LDR 77,1 \% dengan peringkat baik. Sedangkan keempat bank lainnya memperoleh peringkat komposit 3 dengan predikat cukup baik. Rasio LDR Bank Mandiri yaitu 85,86\%, Bank BRI 87,7 \%, Bank BNI 90,4\% dan Bank CIMB Niaga 93,31\%. Semakin tinggi Rasio LDR 
menunjukkan semakin banyak dana yang ditempatkan untuk kredit sehingga likuiditasnya semakin kecil.

Tabel 10. Ringkasan Penilaian LDR 2016

\begin{tabular}{rccccc}
\hline Ket & $\begin{array}{c}\text { Bank } \\
\text { Mandiri }\end{array}$ & BNI & BRI & BCA & $\begin{array}{c}\text { CIMB } \\
\text { Niaga }\end{array}$ \\
\hline LDR (\%) & 85,86 & 90,4 & 87,7 & 77,1 & 93,31 \\
Komposit & 3 & 3 & 3 & 2 & 3 \\
Predikat & $\begin{array}{c}\text { Cukup } \\
\text { baik }\end{array}$ & $\begin{array}{c}\text { Cukup } \\
\text { baik }\end{array}$ & $\begin{array}{c}\text { Cukup } \\
\text { baik }\end{array}$ & Baik & $\begin{array}{c}\text { Cukup } \\
\text { baik }\end{array}$ \\
\hline
\end{tabular}

$\overline{\text { Sumber : Laporan keuangan tahunan bank yang diteliti tahun } 2016}$

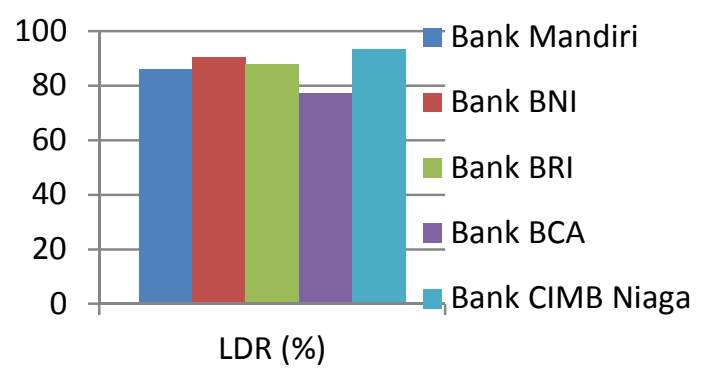

Grafik 2. Perbandingan tingkat LDR pada bank yang diteliti tahun 2016

c. Risiko Pasar

Risiko Pasar diukur dengan menggunakan Interest Rate Risk Ratio (Rasio IRR). Berikut ini hasil penilaian IRR pada tahun 2016 untuk masing-masing bank yang diteliti

Tabel 11. Ringkasan Penilaian IRR tahun 2016

\begin{tabular}{|c|c|c|c|c|c|}
\hline Ket & $\begin{array}{c}\text { Bank } \\
\text { Mandiri }\end{array}$ & BNI & BRI & BCA & $\begin{array}{l}\text { CIMB } \\
\text { Niaga }\end{array}$ \\
\hline IRR (\%) & 312,5 & 310,4 & 351,8 & 480,8 & 272,3 \\
\hline Komposit & 1 & 1 & 1 & 1 & 1 \\
\hline Predikat & $\begin{array}{l}\text { Sangat } \\
\text { baik }\end{array}$ & $\begin{array}{l}\text { Sangat } \\
\text { baik }\end{array}$ & $\begin{array}{l}\text { Sangat } \\
\text { baik }\end{array}$ & $\begin{array}{l}\text { Sangat } \\
\text { baik }\end{array}$ & $\begin{array}{c}\text { Sangat } \\
\text { baik }\end{array}$ \\
\hline
\end{tabular}

Sumber : Data yang diolah peneliti , 2018

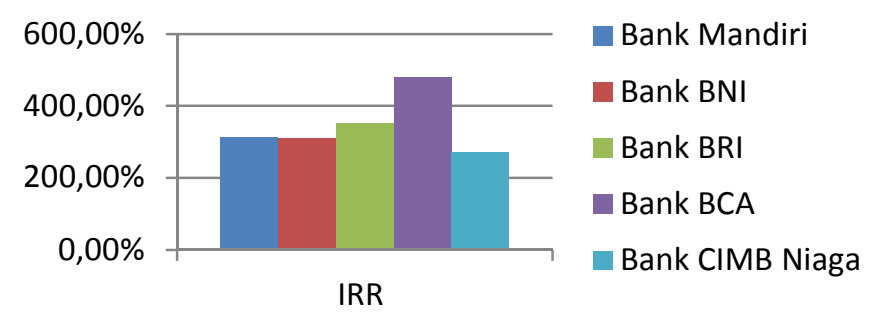

Grafik 3. Perbandingan rasio IRR pada bank yang diteliti tahun 2016 
Berdasarkan penilaian pada risiko pasar dengan menggunakan rasio IRR diperoleh hasil bahwa Bank BCA mempunyai rasio IRR tertinggi yaitu 480,8 \%, diikuti secara berturut-turut oleh Bank BRI dengan rasio IRR 351,8\%, Bank Mandiri 312,5\%, Bank BNI 310,4\% dan Bank CIMB Niaga 272,3\%. Dikarenakan rasio IRR dari kelima bank tersebut lebih tinggi dari $45 \%$, maka semua bank memperoleh Peringkat Komposit 1 dengan predikat sangat baik. Semakin tinggi rasio ini menunjukkan semakin kecil risiko pasar yang terjadi.

\section{Analisis Good Corporate Governance}

Analisis Good Corporate Governance menganut sistem self assessment dimana bank melakukan penilaian sendiri terhadap tata kelola bank dengan memperhatikan berbagai macam aspek. Berikut hasil penilaian GCG untuk periode Desember 2016.

Tabel 12. Ringkasan penilaian GCG pada Bank yang diteliti tahun 2016

\begin{tabular}{cccccc}
\hline Ket & $\begin{array}{c}\text { Bank } \\
\text { Mandiri }\end{array}$ & BNI & BRI & BCA & $\begin{array}{c}\text { Bank } \\
\text { CIMB } \\
\text { Niaga }\end{array}$ \\
\hline $\begin{array}{c}\text { Komposit } \\
\text { Predikat }\end{array}$ & $\begin{array}{c}1 \\
\text { Sangat } \\
\text { baik }\end{array}$ & $\begin{array}{c}2 \\
\text { Baik }\end{array}$ & $\begin{array}{c}2 \\
\text { Baik }\end{array}$ & $\begin{array}{c}\text { Sangat } \\
\text { baik }\end{array}$ & $\begin{array}{c}2 \\
\text { Baik }\end{array}$ \\
\hline
\end{tabular}

Sumber : Laporan keuangan tahunan bank yang diteliti tahun 2016

Berdasarkan hasil self assessment diperoleh hasil penilaian untuk GCG Bank BCA dan Bank Mandiri mendapatkan Peringkat Komposit 1 dengan predikat sangat baik, sedangkan tiga bank lainnya yaitu Bank BRI, BNI dan CIMB Niaga mendapatkan peringkat komposit 2 dengan predikat baik.

\section{Analisis Earnings (Rentabilitas)}

a. Return on Asset

Setelah dilakukan penilaian terhadap Rasio ROA diperoleh hasil sebagai berikut :

Tabel 13. Ringkasan Penilaian ROA pada bank yang diteliti tahun 2016

\begin{tabular}{cccccc}
\hline Ket & $\begin{array}{c}\text { Bank } \\
\text { Mandiri }\end{array}$ & BNI & BRI & BCA & $\begin{array}{c}\text { CIMB } \\
\text { Niaga }\end{array}$ \\
\hline ROA (\%) & 1,95 & 2,7 & 3,84 & 4 & 0,83 \\
Komposit & 1 & 1 & 1 & 1 & 3 \\
Predikat & $\begin{array}{c}\text { Sangat } \\
\text { baik }\end{array}$ & $\begin{array}{c}\text { Sangat } \\
\text { baik }\end{array}$ & $\begin{array}{c}\text { Sangat } \\
\text { baik }\end{array}$ & $\begin{array}{c}\text { Sangat } \\
\text { baik }\end{array}$ & $\begin{array}{c}\text { Cukup } \\
\text { baik }\end{array}$ \\
\hline
\end{tabular}

Sumber : Laporan keuangan tahunan bank yang diteliti tahun 2016

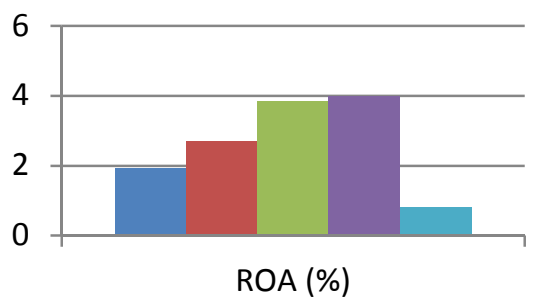

$$
\begin{aligned}
& \text { Bank Mandiri } \\
& \text { Bank BNI } \\
& \text { Bank BRI } \\
& \text { Bank BCA } \\
& \text { Bank CIMB Niaga }
\end{aligned}
$$

Grafik 4. Perbandingan Rasio ROA pada bank yang diteliti tahun 2016 
Berdasarkan penilaian dengan rasio ROA diperoleh hasil bahwa Bank BCA mempunyai rasio ROA tertinggi dengan rasio $4 \%$, diikuti oleh Bank BRI dengan rasio 3,84\%, Bank BNI 2,7 \% dan Bank Mandiri 1,95\%. Keempat bank tersebut memperoleh peringkat komposit 1 dengan predikat Sangat baik untuk rasio ROA, dikarenakan rasionya di atas 1,5\%. Sedangkan Bank CIMB Niaga memperoleh peringkat komposit 3 dengan peringkat cukup baik. Dimana semakin tinggi rasio ROA mengindikasikan semakin baik kemampuan bank dalam memperoleh keuntungan.

\title{
b. Net Interest Margin
}

Berikut ini hasil yang diperoleh dari penilaian rentabilitas menggunakan rasio NIM;

Tabel 14. Ringkasan Penilaian NIM pada Bank yang diteliti tahun 2016

\begin{tabular}{|c|c|c|c|c|c|}
\hline Ket & $\begin{array}{c}\text { Bank } \\
\text { Mandiri }\end{array}$ & $\begin{array}{c}\text { Bank } \\
\text { BNI }\end{array}$ & $\begin{array}{c}\text { Bank } \\
\text { BRI }\end{array}$ & $\begin{array}{l}\text { Bank } \\
\text { BCA } \\
\end{array}$ & $\begin{array}{l}\text { CIMB } \\
\text { Niaga } \\
\end{array}$ \\
\hline NIM (\%) & 6,29 & 6,2 & 8,27 & 6,8 & 5,36 \\
\hline Komposit & 1 & 1 & 1 & 1 & 1 \\
\hline Predikat & $\begin{array}{l}\text { Sangat } \\
\text { baik }\end{array}$ & $\begin{array}{c}\text { Sangat } \\
\text { baik }\end{array}$ & $\begin{array}{c}\text { Sangat } \\
\text { baik }\end{array}$ & $\begin{array}{c}\text { Sangat } \\
\text { baik }\end{array}$ & $\begin{array}{c}\text { Sangat } \\
\text { baik }\end{array}$ \\
\hline
\end{tabular}

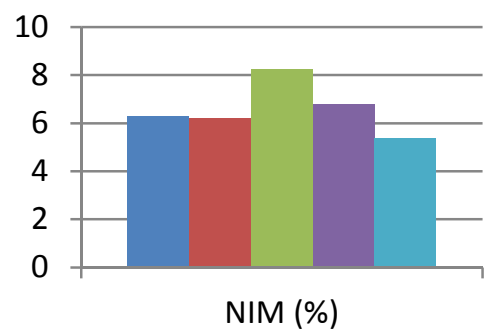

\author{
- Bank Mandiri \\ - Bank BNI \\ Bank BRI \\ Bank BCA \\ Bank CIMB Niaga
}

Grafik 5. Perbandingan rasio NIM pada bank yang diteliti tahun 2016

Hasil penilaian dengan rasio NIM menunjukkan bahwa Bank BRI mempunyai rasio NIM yang paling tinggi dibandingkan dengan bank lain yaitu sebesar $8,27 \%$,diikuti oleh Bank BCA dengan rasio 6,8\%, Bank Mandiri 6,29 \%, Bank BNI 6,2 \% dan Bank CIMB Niaga sebesar 5,36 \%. Untuk kelima bank tersebut mendapatkan peringkat komposit 1 dengan predikat sangat memuaskan, karena rasio NIM diatas $3 \%$. Semakin tinggi rasio NIM menunjukkan semakin baik keinerja bank dalam menhasilkan pendapatan bunga.

\section{Analisis Capital (Permodalan)}

Rasio yang digunakan untuk menilai permodalan adalah rasio Capital Adequacy Ratio (CAR) atau disebut juga dengan Kewajiban Penyediaan Modal Minimum (KPMM). Hasil penilaian rasio CAR diperoleh sebagai berikut pada tabel 15:

Berdasarkan hasil penilaian CAR, Bank BRI mempunyai rasio CAR yang paling tinggi dibanding bank lain yaitu 22,91\%, diikuti oleh Bank BCA dengan rasio CAR 21,9\%, Bank Madiri dengan rasio 21,36 \%, Bank BNI dengan rasio 19,\$\% dan terakhir Bank CIMB Niaga dengan rasio 17,49\%. Dikarenakan rasio CAR kelima bank yang diteliti diatas $12 \%$, maka kelimanya mendapatkan peringkat komposit 1 dengan predikat sangat memadai.Semakin tinggi rasio CAR menunjukkan semakin sehat permodalan bank tersebut. 
Tabel 15. Ringkasan Penilaian CAR pada Bank yang diteliti tahun 2016

\begin{tabular}{clllll}
\hline \multicolumn{1}{c}{ Ket } & $\begin{array}{l}\text { Bank } \\
\text { Mandiri }\end{array}$ & BNI & BRI & BCA & $\begin{array}{l}\text { CIMB } \\
\text { Niaga }\end{array}$ \\
\hline CAR (\%) & 21,36 & 19,4 & 22,91 & 21,9 & 17,49 \\
Komposit & 1 & 1 & 1 & 1 & 1 \\
Predikat & $\begin{array}{l}\text { Sangat } \\
\text { baik }\end{array}$ & $\begin{array}{l}\text { Sangat } \\
\text { baik }\end{array}$ & $\begin{array}{l}\text { Sangat } \\
\text { baik }\end{array}$ & $\begin{array}{l}\text { Sangat } \\
\text { baik }\end{array}$ & $\begin{array}{l}\text { Sangat } \\
\text { baik }\end{array}$ \\
\hline
\end{tabular}

$\overline{\text { Sumber : Laporan keuangan tahunan bank yang diteliti tahun } 2016}$

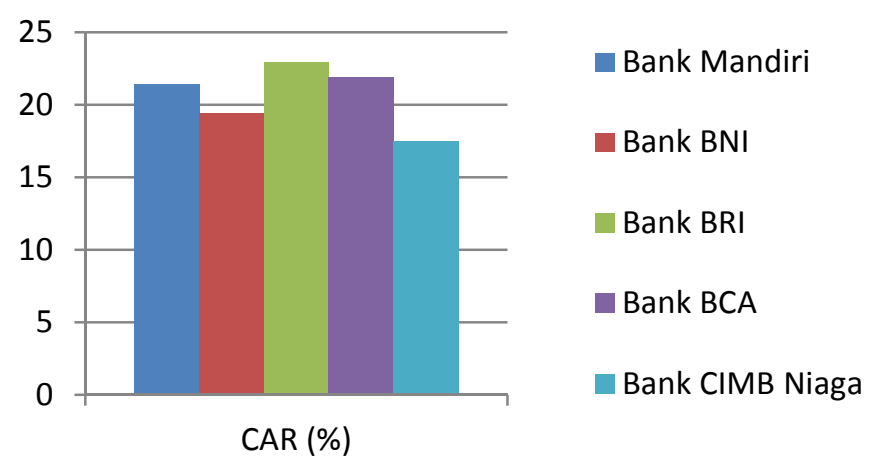

Grafik 6. Perbandingan rasio CAR pada bank yang diteliti tahun 2016

Setelah melakukan perhitungan dan penilaian dari berbagai aspek, selanjutnya menentukan nilai komposit yang diperoleh dengan cara menjumlahkan nilai masingmasing komposit yang dihitung, dibagi dengan jumlah komponen yang ada dan dikalikan dengan $100 \%$. Berikut ini rekapitulasi penilaan peringkat komposit dari masing -masing bank :

\section{a. Bank Mandiri}

Tabel 16. Rekapitulasi Peringkat Komposit Bank Mandiri dari Setiap Komponen RGEC tahun 2016

\begin{tabular}{llllllll}
\hline No & Profil Risiko & Rasio & \multicolumn{5}{c}{ Peringkat } \\
\hline \multirow{2}{*}{1} & \multirow{2}{*}{ Risk Profil } & NPL & 1 & 2 & 3 & 4 & 5 \\
& & LDR & & $\sqrt{ }$ & & & \\
& & IRR & $\sqrt{ }$ & & & \\
2 & GCG & ROA & $\sqrt{ }$ & & & \\
3 & Earnings & NIM & $\sqrt{ }$ & & & \\
& & CAR & $\sqrt{ }$ & & & \\
4 & Capital & 35 & 25 & 4 & 3 & \\
& & & 25 &
\end{tabular}

Sumber : Data yang diolah peneliti, 2018

Dari rekapitulasi penilaian peringkat komposit masing-masing aspek, dapat dihitung bobot nilai kesehatan bank Mandiri sebagai berikut :

Nilai Kesehatan Bank (Mandiri tahun 2016) $=\frac{32}{35} \times 100 \%=91,43 \%$ 


\section{b. Bank BNI}

Tabel 17. Rekapitulasi Peringkat Komposit Bank BNI dari Setiap Komponen RGEC tahun 2016

\begin{tabular}{llllclll}
\hline No & Profil Risiko & Rasio & \multicolumn{5}{c}{ Peringkat } \\
\hline & \multirow{2}{*}{ Risk Profil } & NPL & & $\sqrt{ }$ & & & \\
& & LDR & & & $\sqrt{ }$ & & \\
& & IRR & $\sqrt{ }$ & & & \\
& & & & $\sqrt{ }$ & & \\
2 & GCG & ROA & $\sqrt{ }$ & & & \\
3 & Earnings & NIM & $\sqrt{ }$ & & & \\
& & CAR & $\sqrt{ }$ & & & \\
4 & Capital & 35 & 20 & 8 & 3 & \\
& & & 35 &
\end{tabular}

Sumber : Data yang diolah peneliti, 2018

Dari rekapitulasi penilaian peringkat komposit masing-masing aspek, dapat dihitung bobot nilai kesehatan bank BNI sebagai berikut :

$$
\text { Nilai Kesehatan Bank (BNI tahun 2016) }=\frac{31}{35} \times 100 \%=88,57 \%
$$

\section{c. Bank BRI}

Tabel 18. Rekapitulasi Peringkat Komposit Bank BRI dari Setiap Komponen RGEC tahun 2016

\begin{tabular}{|c|c|c|c|c|c|c|c|}
\hline No & Profil Risiko & Rasio & \multicolumn{5}{|c|}{ Peringkat } \\
\hline \multirow{4}{*}{1} & & & 1 & 2 & 3 & 4 & 5 \\
\hline & Risk Profil & NPL & & $\sqrt{ }$ & & & \\
\hline & & LDR & & & $\sqrt{ }$ & & \\
\hline & & IRR & $\sqrt{ }$ & & & & \\
\hline 2 & GCG & & & $\sqrt{ }$ & & & \\
\hline \multirow[t]{2}{*}{3} & Earnings & ROA & $\sqrt{ }$ & & & & \\
\hline & & NIM & $\sqrt{ }$ & & & & \\
\hline \multirow[t]{2}{*}{4} & Capital & CAR & $\sqrt{ }$ & & & & \\
\hline & & 35 & 20 & 8 & 3 & & \\
\hline
\end{tabular}

Sumber : Data yang diolah peneliti, 2018

Dari rekapitulasi penilaian peringkat komposit masing-masing aspek, dapat dihitung bobot nilai kesehatan bank BRI sebagai berikut :

$$
\text { Nilai Kesehatan Bank (BRI tahun 2016) }=\frac{31}{35} \times 100 \%=88,57 \%
$$

\section{d. Bank BCA}

Dari rekapitulasi penilaian peringkat komposit masing-masing aspek, dapat dihitung bobot nilai kesehatan bank BCA sebagai berikut:

$$
\text { Nilai Kesehatan Bank (BCA tahun 2016) }=\frac{34}{35} \times 100 \%=97,14 \%
$$


Tabel 19. Rekapitulasi Peringkat Komposit Bank BCA dari Setiap Komponen RGEC tahun 2016

\begin{tabular}{llllllll}
\hline No & Profil Risiko & Rasio & \multicolumn{4}{c}{ Peringkat } \\
\hline \multirow{2}{*}{1} & \multirow{2}{*}{ Risk Profil } & NPL & $\sqrt{ }$ & 2 & 3 & 4 & 5 \\
& & LDR & & $\sqrt{ }$ & & \\
& & IRR & $\sqrt{ }$ & & & \\
2 & GCG & & $\sqrt{ }$ & & & \\
3 & Earnings & ROA & $\sqrt{ }$ & & & \\
& & NIM & $\sqrt{ }$ & & & \\
4 & Capital & CAR & $\sqrt{ }$ & & & \\
& & 35 & 30 & 4 & \\
\hline
\end{tabular}

Sumber : Data yang diolah peneliti, 2018

\section{e. Bank CIMB Niaga}

Tabel 20. Rekapitulasi Peringkat Komposit Bank CIMB Niaga dari Setiap Komponen RGEC tahun 2016

\begin{tabular}{llllllll}
\hline No & Profil Risiko & Rasio & \multicolumn{5}{c}{ Peringkat } \\
\hline \multirow{2}{*}{1} & \multirow{2}{*}{ Risk Profil } & NPL & & $\sqrt{ }$ & 3 & 4 & 5 \\
& & LDR & & & $\sqrt{ }$ & & \\
& & IRR & $\sqrt{ }$ & & & & \\
2 & GCG & & & $\sqrt{ }$ & & & \\
3 & Earnings & ROA & & & $\sqrt{ }$ & & \\
& & NIM & $\sqrt{ }$ & & & & \\
4 & Capital & CAR & $\sqrt{ }$ & & & & \\
& & 35 & 15 & 8 & 6 & & \\
\hline
\end{tabular}

Sumber : Data yang diolah peneliti, 2018

Dari rekapitulasi penilaian peringkat komposit masing-masing aspek, dapat dihitung bobot nilai kesehatan bank CIMB Niaga sebagai berikut

Nilai Kesehatan Bank (CIMB Niaga tahun 2016) $=\frac{29}{35} \times 100 \%=82,86 \%$

Berikut ini disajikan perbandingan hasil akhir penilaian kesehatan bank pada bank yang diteliti berdasarkan urutan nilai bobot tertinggi;

Tabel 21. Perbandingan Hasil Akhir Penilaian Kesehatan Bank Berdasarkan Nilai Bobot Tertinggi

\begin{tabular}{llcl}
\hline No & Nama Bank & $\begin{array}{c}\text { Bobot } \\
\text { Komposit } \\
\mathbf{( \% )}\end{array}$ & Keterangan \\
\hline 1 & Bank BCA & 97,14 & Sangat Sehat \\
2 & Bank Mandiri & 91,43 & Sangat Sehat \\
3 & Bank BRI & 88,57 & Sangat Sehat \\
4 & Bank BNI & 88,57 & Sangat sehat \\
5 & Bank CIMB & 82,86 & Sehat \\
& Niaga & & \\
\hline
\end{tabular}

Sumber : Data yang diolah peneliti, 2018 
Berdasarkan hasil rekapitulasi penilaian kesehatan bank dengan menggunakan metode RGEC, diperoleh hasil bahwa Bank BCA memperoleh nilai bobot komposit paling tinggi yaitu 97,14 \%, kemudian Bank Mandiri dengan nilai bobot komposit 91,43\%, Bank BRI dan Bank BNI dengan nilai bobot komposit masing-masing 88,57\%. Keempat bank tersebut masuk dalam kategori penilaian Sangat Sehat, dikarenakan nilai bobot kompositnya lebih dari 86\%. Sedangkan Bank CIMB Niaga mendapatkan penilaian paling rendah dibandingkan bank lain yang diteliti dengan nilai bobot komposit 82,86\% sehingga masuk dalam kategori penilaian Sehat.

\section{KESIMPULAN}

Penelitian dilakukan untuk menganalisis tingkat kesehatan bank dengan metode RGEC pada lima bank yang masuk kategori BUKU 4 pada tahun 2016, yaitu pada Bank Mandiri, Bank BNI, Bank BRI, Bank BCA dan Bank CIMB Niaga. Sebagai perbandingan diantara kelima bank tersebut, untuk penilaian Risk Profile dengan menggunakan komponen NPL, Bank BCA memiliki rasio yang paling baik yaitu rasio yang paling rendah sebesar 1,31\% yang mengindikasikan Bank BCA memiliki jumlah kredit bermasalah yang paling kecil dibandingkan keempat bank lain yang diteliti. Sedangkan untuk rasio LDR Bank BCA juga memiliki rasio yang paling baik yaitu 77,1 $\%$ sehingga masuk dalam peringkat komposit 2. Berdasarkan hasil rasio IRR, Bank BCA juga memperoleh rasio yang paling baik yaitu $480,8 \%$ dan memperoleh peringkat komposit 1. Penilaian Good Corporate Governance (GCG) yang dilakukan sendiri oleh masing-masing bank, Bank BCA dan Bank Mandiri memperoleh penilaian yang menghasilkan peringkat komposit 1. Sedangkan untuk menilai Earnings dengan menggunakan rasio ROA, Bank BCA memperoleh rasio yang paling baik dengan rasio 4 $\%$ sehingga memperoleh peringkat komposit 1 . Untuk komponen NIM, Bank BRI memperoleh memperoleh rasio tertinggi dengan rasio $8,27 \%$. Sedangkan untuk menilai aspek Permodalam (Capital) dengan menggunakan rasio CAR, Bank BCA memperoleh rasio yang tertinggi dengan rasio $22,91 \%$. Dari hasil penelitian tersebut, diperoleh hasil bahwa kondisi kesehatan kelima bank tersebut tergolong baik. Dimana Bank BCA memperoleh nilai bobot 97,14\%, Bank Mandiri 91,43\%, Bank BRI dan Bank BNI memperoleh nilai bobot $88,57 \%$. Berdasarkan hasil tersebut, maka keempat bank diatas mendapatkan predikat Sangat Sehat karena nilai bobot komposit diatas $86 \%$. Sedangkan Bank CIMB Niaga dengan nilai bobot komposit sebesar 82,86\% memperoleh predikat Sehat.

\section{SARAN}

Berdasarkan hasil penelitian yang telah dipaparkan, penulis mengajukan saran agar kelima bank yang diteliti tetap mempertahankan kesehatan banknya, mengingat kesehatan bank merupakan salah satu tolak ukur kepercayaan masyarakat kepada pihak bank. Kelima bank yang diteliti diharapkan lebih memperhatikan lagi risiko likuiditasnya, karena dengan alat likuid yang terjaga dengan baik bank akan mampu mengembalikan simpanan nasabahnya jika sewaktu waktu diambil dan akan mampu memenuhi komitmen kreditnya sesuai dengan kesepakatan.

DAFTAR PUSTAKA

Bank Indonesia. 1998. UU No. 10 tahun 1998 tentang Perubahan Terhadap UU No. 7 tahun 1992. Jakarta

Bank Indonesia. 2011. Peraturan Bank Indonesia No 13/1/PBI/2011 tentang Penilaian Tingkat Kesehatan Bank Umum 
2011. Surat Edaran Bank Indonesia No 13/24/DPNP tentang Matriks Perhitungan Analisis Komponen Faktor Analisis RGEC untuk Bank Umum

------------------. 2012. Kodifikasi Bank Indonesia Penilaian Tingkat Kesehatan Bank

-2013. Peraturan Bank Indonesia No 15/12/PBI/2013 tentang Kewajiban

Penyediaan Modal Minimum Bank Umum

Budisantoso, Totok dan Sigit Triandaru. 2006. Bank dan Lembaga Keuangan lain. Edisi kedua. Jakarta : Salemba Empat.

Laporan Tahunan Bank Mandiri 2016. Terpublikasikan melalui website : ir.bankmandiri.co.id

Laporan Tahunan Bank Negara Indonesia 2016. Terpublikasikan melalui website : $\underline{w w w . b n i . c o . i d}$

Laporan Tahunan Bank Rakyat Indonesia 2016. Terpublikasikan melalui website : www.ir-bri.com

Laporan Tahunan Bank Central Asia 2016. Terpublikasikan melalui website : www.bca.co.id

Laporan Tahunan Bank CIMB Niaga 2016. Terpublikasikan melalui website : www.cimbniaga.com

Otoritas Jasa Keuangan. 2016. Peraturan OJK No. 6 /POJK.03/2016 tentang Kegiatan Usaha dan Jaringan Kantor Berdasarkan Modal Inti Bank

Riyadi, Slamet. 2006. Banking Assets and Liability Management. Edisi Ketiga. Jakarta. Lembaga Penerbitan FE Universitas Indonesia

Setiawan, Ngadirin. 2012. Analisis Laporan Keuangan : Penilaian Kesehatan Bank. Yogyakarta : Universitas Negeri Yogyakarta

Taswan. 2010. Manajemen Perbankan, Konsep, Teori dan Aplikasi. Yogyakarta: UMP STIM YKPN.

Triandaru, Sigit dan Budisantoso. 2006. Bank dan Lembaga Keuangan Lainnya. Yogyakarta: Salemba Empat

Permana, Bayu Aji. 2012. Analisis Tingkat Kesehatan Bank Berdasarkan Metode CAMELS dan Metode RGEC. Skripsi. Surabaya: Universitas Negeri Surabaya. 